\title{
ANALISIS KEMANDIRIAN FISKAL DI KABUPATEN JAYAPURA
}

\author{
Penulis \\ Dwi Fitriani ${ }^{1}$ \\ dwifitriani025@gmail.com \\ Yundy Hafizrianda ${ }^{2}$ \\ apitika@yahoo.com \\ Ida Ayu Purba Riani ${ }^{3}$ \\ purbariani@gmail.com
}

\begin{abstract}
This study aims to analyse the financial dependence of Jayapura Regency on the Central Government for the period of 2012 - 2016. The study found that regional income has not been fully realised so that the level of regional dependence is still in position and an instructive pattern.
\end{abstract}

Keywords: fiscal dependence, regional income

\section{PENDAHULUAN}

Penyelenggaraan Pemerintah di sejumlah Negara, termasuk di Indonesia cenderung bergerak ke arah desentralisasi. Dorongan desentralisasi yang terjadi pada berbagai Negara di dunia termasuk negara - negara Arah berkembang di pengaruhi oleh beberapa hal antara lain : latar belakang suatu Negara, kemunduran dalam pembangunan ekonomi, peranan Negara tersebut dalam globalisasi dunia, tanda tanda adanya disintregrasi di beberapa Negara akibat ketidakpuasan terhadap layanan public oleh pemerintah pusat secara efektif dan efisien. Oleh karena itu desentralisasi di lakukan sebagai salah satu upaya mereformasi dan memodernisasi pemerintahannya. Secara teoritis, desentralisasi di pahami sebagai penyerahan otoritas dan fungsi dari pemerintah nasional kepada pemerintah sub-nasional atau lembaga independen.

Memperhatikan berbagai hasil kajian para ahli menunjukkan bahwa otonomi daerah selama ini tergolong sangat kecil dilihat dari indikator kecilnya kewenangan, jumlah bidang Pemerintahan, dan Pendapatan Asli Daerah (PAD) yang dimiliki daerah Hoessein (2000). Hal ini merupakan gambaran dari praktek pemerintah masa lalu yang dilandasi oleh Undang-Undang Nomor 5 Tahun 1974. Dengan berpegang pada

\footnotetext{
${ }^{1}$ Alumni Mahasiswa Magister Keuangan Daerah Universitas Cenderawasih

2 Staf Dosen Jurusan Ekonomi Fakultas Ekonomi \& Bisnis Universitas Cenderawasih

${ }^{3}$ Staf Dosen Jurusan Ekonomi Fakultas Ekonomi \& Bisnis Universitas Cenderawasih
} 
Undang-Undang tersebut, maka praktek yang terjadi dilapangan berupa sentralisasi kekuasaan yang sangat kuat, sehingga masyarakat di daerah tidak memiliki kekuasaan dan kesempatan untuk mengaktualisasikan kepentingan dan potensi daerahnya sendiri Mardiasmo (2009:3), 2015).

Mulyana, (2006) mengatakan, akhir - akhir ini, dalam membicarakan masalah sistem pemerintah yang efektif dan efisien baik di negara maju maupun negara berkembang, desentralisasi fiskal telah menjadi isu yang semakin hangat dan semakin berkembang. Di Indonesia dalam beberapa dekade ini, meskipun lambat, telah terjadi perkembangan yang semakin baik dalam penerapan desentralisasi fiskal, terutama berkenaan dengan perencanaan pembangunan keuangan (development and financial planning).

Penerapan otonomi daerah diberlakukan sejak tanggal 1 Januari 2001 membawa implikasi pada pelimpahan wewenang antara pusat dan daerah dalam berbagai bidang. Kebijakan terkait yang tertuang dalam UU No. 22 tahun 1999 tentang Pemerintahan Daerah dan UU No 25 tahun 1999 tentang Perimbangan Keuangan antara Pemerintah Pusat dan Daerah. Undang - Undang ini dalam perkembangannya diperbaharui dengan dikeluarkannya UU No.32 tahun 2004. Diberlakukannya undangundang ini memberikan peluang bagi daerah untuk menggali potensi lokal dan meningkatkan kinerja keuangannya dalam rangka mewujudkan kemandirian daerah. Undang-Undang No. 32 Tahun 2004 dan Undang-Undang No. 33 Tahun 2004 dikenal dengan Undang-Undang Otonomi Daerah, merupakan pijakan hukum atas implementasi desentralisasi fiskal di Indonesia. Dengan ditetapkannya UndangUndang No. 32 Tahun 2004, maka akan terjadi perluasan wewenang pemerintah daerah. Sedangkan Undang-Undang No. 33 Tahun 2004 akan tercipta peningkatan kemampuan keuangan daerah.

Pelaksanaan otonomi daerah merupakan proses yang memerlukan keterlibatan segenap unsur dan lapisan masyarakat, serta memberikan kekuasaan bagi pemerintah daerah dalam melakukan pengelolaan keuangan daerah sehingga peran pemerintah adalah sebagai katalisator dan fasilitator karena pihak pemerintahlah yang lebih mengetahui sasaran dan tujuan pembangunan yang akan dicapai. Sebagai katalisator dan fasilitator tentunya membutuhkan berbagai sarana dan fasilitas pendukung dalam rangka terlaksananya pembangunan secara berkesinambungan.

Salah satu desentralisasi yang paling banyak disoroti dan paling banyak berpengaruh terhadap perkembangan pembangunan daerah adalah desentralisasi fiskal yang merupakan bagian terpenting dalam implementasi otonomi daerah. Desentralisasi fiskal merupakan pedelegasian tanggungjawab, otoritas dan sumber sumber yang berkaitan dari pemerintah pusat kepada tingkatan pemerintahyang lebih 
rendah. Alasan mengapa suatu Negara menerapkan prinsip desentralisasi fiskal adalah karena pengambilan keputusan akan lebih baik apbila pengambilan keputusan diserahkan kepada tingkatan pemerintah yang lebih rendah yang secara lagsung dapat merasakan dampak dari program dan pelayanan yang direncanakan oleh Pemerintah Mulyana, (2006).

Untuk meningkatkan pendapatan daerah pada dewasa ini masing-masing daerah dituntut harus mampu berusaha untuk meningkatkan pendapatannya, maka penggalian potensi ekonomi daerah dan penggunaan potensi yang tepat adalah jalan terbaik, karena tanpa memperhitungkan potensi yang dimiliki oleh masing-masing daerah serta tanpa pengembangan pembangunan dan pendapatan daerah tidak akan mencapai hasil yang optimal atau sesuai dengan yang diharapkan. Potensi ekonomi daerah merupakan kemampuan ekonomi yang ada di daerah yang mungkin dan layak dikembangkan sehingga akan terus berkembang menjadi sumber kehidupan rakyat setempat bahkan dapat menolong perekonomian secara keseluruhan untuk berkembang dengan sendirinya dan berkesinambungan Suparmoko, (2002).

Berdasarkan BPS, 2016. Pertumbuhan ekonomi Kabupaten Jayapura pada tahun 2016 mengalami perlambatan dibanding tahun 2015. Laju pertumbuhan PDRB Kabupaten Jayapura tahun 2016 sebesar 8.54 persen, lebih lambat dibanding tahun 2015 yang tumbuh 9.95 persen. Sedangkan pertumbuhan ekonomi Kabupaten Jayapura pada tahun 2014 sebesar 11.27 persen dan 10.20 persen pada tahun 2013 . Secara berurutan, pertumbuhan tujuh belas kategori lapangan usaha Kabupaten Jayapura adalah : lapangan usaha Pengadaan Listrik dan Gas sebesar 18.43 persen, lapangan usaha Transportasi dan Pergudangan sebesar 15.76 persen, lapangan usaha Kontruksi sebesar 15.34 persen, lapangan usaha Jasa Perusahaan sebesar 15.06 persen, lapangan usaha Real Estat sebesar 9.93 persen, lapangan Penyediaan Akomodasi dan Makan Minum sebesar 9.51 persen, lapangan usaha Jasa Keuangan sebesar 9.07 persen, lapangan usaha Informasi dan Komunikasi tumbuh sebesar 9.05 persen, lapangan usaha Administrasi Pemerintahan, Pertahanan dan Jaminan Sosial Wajib sebesar 8.95 persen, lapangan usaha Jasa Kesehatan dan Kegiatan Sosial sebesar 8.89 persen, lapangan usaha Jasa Pendidikan sebesar 8.73 persen, lapangan usaha Jasa lainnya sebesar 7.51 persen, Reparasi Mobil dan Sepeda Motor sebesar 6.96 persen lapangan usaha Pengadaan Air, Pengelolaan Sampah, Limbah dan Daur Ulang sebesar 6.08 persen, lapangan usaha Perdagangan Besar dan Eceran; lapangan usaha Industri Pengolahan sebesar 5.81 persen, lapangan usaha Pertanian, Kehutanan, dan Perikanan sebesar 1.82 persen, dan lapangan usaha Pertambangan dan Penggalian tumbuh sebesar 0.22 persen. 
Dengan melihat kondisi diatas, hal tersebut juga diperkuat dengan pernyataan yang dipublikasikan pada media online, antara lain sebagai berikut :

("Menurut Mathius Awoitauw," n.d.), menyebut pertumbuhan ekonomi Kabupaten Jayapura tahun 2012 telah berda di atas 10 persen dan terus mengalami peningkatan hingga tahun 2014 yang telah mencapai 11,74 persen, tahun 2015 ini diperkirakan dapat dipertahankan pertumbuhan ekonomi diatas 2 digit. Sementara itu, untuk PDRB perkapital Kabupaten Jayapura pada tahun 2014 telah mencapai Rp. 62 juta perkapital, meningkat sekitar Rp. 10 juta bila dibandingkan dengan tahun 2013. Angka sementara tahun 2015 berada di angka Rp. 63,5 juta. "Pertumbuhan ekonomi Kabupaten Jayapura sangat dipengaruhi oleh pertumbuhan sektoral. Sektor yang membrikan konstribusi besar terhadap pertumbuhan ekonomi Kabupaten Jayapura adalah sector pertanian, kehutanan dan perikanan (24,22 persen), sector transportasi dan pergudangan 17,11 persen, sektor perdagangan besar dan enceran, reparasi dan sepeda motor 12,26 persen dan sektor konstruksi 12,05 persen.

("Menurut Jefri De Fretes," n.d.), tingkat pertumbuhan ekonomi tertinggi di Provinsi Papua adalah di Kabupaten Jayapura. Data BPS Kabupaten Jayapura mencatat, tingkat pertumbuhan ekonomi di wilayah ini mencapai $11 \%$ di Tahun 2014. indikator dari peningkatan pertumbuhan ekonomi di daerah ini sangat dipengaruhi oleh Pendapatan Domestik Regional Bruto (PDRB). Dimana transaksi jual beli yang dilakukan oleh masyarakat dinilai tertinggi di Papua.

Beranjak dari hal di atas, maka kemampuan Pemerintah Daerah Kabupaten Jayapura dalam mengelola keuangan dituangkan dalam APBD yang langsung maupun tidak langsung mencerminkan kemampuan pemerintah daerah dalam membiayai pelaksanaan tugas-tugas pemerintahan, pembangunan dan pelayanan sosial masyarakat. Untuk itu evaluasi terhadap pengelolaan keuangan daerah dan pembiayaan keuangan daerah akan sangat menentukan kedudukan suatu pemerintah daerah. Berdasarkan data APBD Kabupaten Jayapura selama 5 (lima) tahun anggaran, pada posisi pendapatan menunjukkan bahwa Dana Perimbangan masih mendominasi penerimaan daerah dibandingkan dengan PAD. Hal ini mengindikasikan masih tingginya ketergantungan fiskal Pemerintah Daerah Kabupaten Jayapura terhadap Pemerintah Pusat selama kurun waktu 2012-2016.

\section{METODE PENELITIAN}

Tehnik analisia dalam penelitian ini memakai analisis Studi kepustakaan menjadi salah satu teknik pengumpulan data dan infromasi melalui buku-buku, karya ilmiah, 
jurnal, laporan pemrintah, dokumen yang diakses melalui internet. Metode ini digunakan untuk mendapatkan hasil yang optimal.

Selanjutnya pemilihan tehnik analisis deskriptif digunakan untuk memberikan gambaran mengenai variabel penelitian. Statistik deskriptif yang digunakan antara lain analisis perkembangan pendapatan daerah dan analisis rasio keuangan.

\section{PEMBAHASAN}

Rasio Kemandirian Keuangan Daerah Kabupaten Jayapura. Berdasarkan hasil penelitian penulis dengan menggunakan data-data sekunder yang diperoleh, maka tingkat kemandirian keuangan daerah Kabupaten Jayapura dapat dilihat pada tabel berikut ini:

Tabel 1.

Rasio Kemandirian Keuangan Daerah Kabupaten Jayapura Tahun 2012-2016

\begin{tabular}{|c|c|c|c|c|}
\hline Tahun & $\begin{array}{c}\text { Pendapatan } \\
\text { Asli Daerah } \\
\text { (PAD) }\end{array}$ & $\begin{array}{c}\text { Dana } \\
\text { Perimbangan }\end{array}$ & $\begin{array}{c}\text { Rasio } \\
\text { Kemandirian }\end{array}$ & $\begin{array}{c}\text { Pola } \\
\text { Hubungan }\end{array}$ \\
\hline 2012 & $\begin{array}{l}32.544 .334 .95 \\
8\end{array}$ & 598.279.667.656 & 5,44 & Instruktif \\
\hline 2013 & $\begin{array}{l}41.914 .407 .61 \\
5\end{array}$ & 636.419 .891 .977 & 6,59 & Instruktif \\
\hline 2014 & $\begin{array}{l}80.133 .491 .08 \\
8\end{array}$ & 708.726.243.361 & 11,31 & Instruktif \\
\hline 2015 & $\begin{array}{l}74.130 .385 .45 \\
9\end{array}$ & 832.967.467.644 & 8,90 & Instruktif \\
\hline 2016 & $\begin{array}{l}87.394 .171 .93 \\
7\end{array}$ & $\begin{array}{l}1.020 .402 .973 .15 \\
7\end{array}$ & 8,56 & Instruktif \\
\hline \multicolumn{3}{|c|}{ Rata-Rata } & 8,16 & \\
\hline
\end{tabular}

\section{Sumber : Data di Olah, 2018}

Berdasarkan tabel 4.3 di atas menjelaskan bahwa, rata-rata tingkat kemandirian keuangan daerah Kabupaten Jayapura selama periode tahun anggaran 2012-2016 sebesar $8,16 \%$, sehingga diklasifikasikan menurut kriteria penilaian kemandirian keuangan daerah posisi tingkat kemandirian keuangan Kabupaten Jayapura yakni masih rendah. Hal ini menunjukkan bahwa Kabupaten Jayapura selama periode tahun anggaran 2012-2016 memiliki ketergantungan tinggi terhadap bantuan pemerintah pusat melalui dana perimbangan/dana transfer, dan jika dihubungkan dengan pola 
hubungan antara pemerintah pusat dan daerah, maka Kabupaten Jayapura masuk dalam kategori pola hubungan instruktif, dimana peranan pemerintah pusat lebih dominan daripada kemandirian pemerintah daerah. Rasio Kemadirian yang masih rendah menunjukan bahwa pada sumber penerimaan daerah masih kurang maksimal.

Hal ini dikarenakan masih relatif kurangnya PAD yang dapat digali oleh pemerintah daerah sehingga kemampuan keuangan daerah Kabupaten Jayapura dalam membiayai pelaksanaan pemerintahan dan pembangunan masih sangat tergantung pada penerimaan dari pemerintah pusat.

Menurut kriteria penilaian kemandirian keuangan daerah posisi tingkat kemandirian keuangan Kabupaten Jayapura yakni masih rendah. Hal ini menunjukkan bahwa Kabupaten Jayapura selama periode tahun anggaran 2012-2016 memiliki ketergantungan tinggi terhadap bantuan pemerintah pusat melalui dana perimbangan/dana transfer, dan jika dihubungkan dengan pola hubungan antara pemerintah pusat dan daerah, maka Kabupaten Jayapura masuk dalam kategori pola hubungan instruktif, dimana peranan pemerintah pusat lebih dominan daripada kemandirian pemerintah daerah. Rasio Kemadirian yang masih rendah menunjukan bahwa pada sumber penerimaan daerah masih kurang maksimal. Hal ini dikarenakan masih relatif kurangnya PAD yang dapat digali oleh pemerintah daerah sehingga kemampuan keuangan daerah Kabupaten Jayapura dalam membiayai pelaksanaan pemerintahan dan pembangunan masih sangat tergantung pada penerimaan dari pemerintah pusat.

Untuk mengatasi hal tersebut, pemerintah daerah harus mampu mengoptimalkan penerimaan dari potensi pendapatannya yang telah ada. Hal tersebut tidak lepas dari inisiatif dan kemauan pemerintah daerah sangat diperlukan dalam upaya meningkatkan PAD. Pemerintah daerah harus mencari alternatif-alternatif yang memungkinkan untuk dapat mengatasi kekurangan pembiayaannya, dan hal ini memerlukan kreaitifitas dari aparat pelaksana keuangan daerah untuk mencari sumber-sumber pembiayaan baru baik melalui program kerjasama pembiayaan dengan pihak swasta dan juga program peningkatan PAD misalnya dengan melihat pada potensi sumber daya alam (SDA).

Analisis Time Trend. suatu metode analisis yang ditujukan untuk melakukan suatu estimasi atau peramalan pada masa yang akan datang. Berdasarkan perhitungan yang dilakukan maka hasil yang di peroleh dapat dilihat pada tabel: 
Tabel 2.

Peramalan Kemandirian Fiskal Kabupaten Jayapura ( $t+)$

\begin{tabular}{|c|c|c|}
\hline Tahun +t & $\begin{array}{c}\text { Peramalan } \\
\text { Kemandirian Fiskal }\end{array}$ & $\begin{array}{c}\text { Pola } \\
\text { Hubungan }\end{array}$ \\
\hline 2017 & 13,08 & Instruktif \\
\hline 2018 & 14,82 & Instruktif \\
\hline 2019 & 16,56 & Instruktif \\
\hline 2020 & 18,30 & Instruktif \\
\hline 2021 & 20,04 & Instruktif \\
\hline
\end{tabular}

\section{Sumber: Data di olah,2018}

Dari table diatas dapat dilihat bahwa hasil ramalan tingkat kemandirian fiskal/kemampuan keuangan pemerintah daerah dalam membiayai sendiri kegiatan pemerintahan, pembangunan, dan pelayanan kepada masyarakat untuk peramalan lima tahun dari tahun 2016, maka posisi pola hubungan kemandirian fiskal kabupaten jayapura masih berada pada pola instruktif. Dari hasil tersebut dapat dikatakan, jika Pemerintah Kabupaten Jayapura masih menggunakan pola Pemerintahan yang sama seperti tahun-tahun sebelumnya, maka pola hubungan kemandirian fiskal untuk lima tahun yakni tahun 2017-2021 masih berada pada pola hubungan instruktif.

Hal tersebut menjadi masukan untuk pemerintah kabupaten jayapura agar dapat melakukan optimalisasi-optimalisasi terhadap pendapatan asli daerah (PAD). Namun demikian, penggalian sumber penerimaan baru diharapkan tidak menimbulkan terjadinya distorsi kegiatan ekonomi di daerah, misalnya menyebabkan ekonomi biaya tinggi sehingga menimbulkan keengganan investor baru masuk dalam bisnis di daerah.Di samping itu, kebijakan pemerintah daerah tentang pajak/retribusi daerah tidak menimbulkan kelesuan iklim berusaha di kalangan pengusaha daerah

Rasio Desentralisasi Fiskal Kabupaten Jayapura. Tingkat Desentralisasi Fiskal adalah ukuran untuk menunjukkan tingkat kewenangan dan tanggung jawab yang diberikan pemerintah pusat kepada pemerintah daerah untuk melaksanakan pembangunan. Tingkat desentralisasi fiskal dalam penelitian ini diukur dengan menggunakan rasio PAD terhadap total penerimaan daerah. Secara umum, semakin tinggi Skala Interval Derajat Desentralisasi Fiskal berarti semakin tinggi tingkat Kemampuan Keuangan Daerah untuk membiayai pembangunan daerahnya. Dan sebaliknya, semakin rendah Skala Interval Derajat Desentralisasi Fiskal berarti 
semakin rendah Kemampuan Keuangan Daerah untuk membiayai pembangunan daerahnya. Berdasarkan hasil penghitungan yang dilakukan penulis, diperoleh besarnya rasio desentralisasi fiskal Kabupaten Jayapura tahun 2012-2016 sebagai berikut:

Tabel 3.

Rasio Desentralisasi Fiskal Kabupaten Jayapura

Tahun 2012-2016

\begin{tabular}{|c|c|c|c|c|}
\hline Tahun & $\begin{array}{c}\text { Pendapatan Asli } \\
\text { Daerah (PAD) }\end{array}$ & Total Penerimaan & $\begin{array}{c}\text { Rasio } \\
\text { Desentralisasi }\end{array}$ & Keterangan \\
\hline 2012 & 32.544 .334 .958 & 751.825 .610 .630 & 4,33 & $\begin{array}{c}\text { Sangat } \\
\text { Kurang }\end{array}$ \\
\hline 2013 & 41.914 .407 .615 & 863.347 .739 .128 & 4,85 & $\begin{array}{c}\text { Sangat } \\
\text { Kurang }\end{array}$ \\
\hline 2014 & 80.133 .491 .088 & 1.003 .664 .252 .764 & 7,98 & $\begin{array}{c}\text { Sangat } \\
\text { Kurang }\end{array}$ \\
\hline 2015 & 74.130 .385 .459 & 1.186 .438 .268 .365 & 6,25 & $\begin{array}{c}\text { Sangat } \\
\text { Kurang }\end{array}$ \\
\hline 2016 & 87.394 .171 .937 & 1.409 .107 .490 .955 & 6,20 & $\begin{array}{c}\text { Sangat } \\
\text { Kurang }\end{array}$ \\
\hline \multicolumn{2}{|c|}{ Rata - Rata } & 5,92 & \\
\hline
\end{tabular}

Sumber : Data di Olah, 2018

Dari hasil perhitungan Rasio Desentralisasi Fiskal tersebut dapat dilihat bahwa tingkat kemampuan pemerintah daerah Kabupaten Jayapura dalam melaksanakan otonomi daerah selama tahun 2012-2016 dalam hal peningkatan Pendapatan Asli Daerah masih sangat kurang karena hanya memberikan kontribusi rata-rata sebesar $5,92 \%$ dari total pendapatan daerah.

\section{KESIMPULAN}

Mencermati hasil analisis pada penelitian mengenai kemandirian fiskal di Kabupaten Jayapura, maka dapat di tarik kesimpulan yankni :

- Kontribusi Dana Transfer/Perimbangan terhadap pendapatan daerah Kabupaten Jayapura masih cukup tinggi, yakni dengan rata-rata kontribusi sebesar 73,31\%.

- Tingkat ketergantungan fiskal di Kabupaten Jayapura masih sangat tinggi. Sehingga kemandirian fiskalnya menjadi rendah. Dengan kondisi seperti ini maka Kabupaten Jayapura tergolong dalam pola hubungan yang instruktif terhadap pemerintah pusat, dimana peranan pusat masih sangat dominan untuk memenuhi belanja daerah. 


\section{DAFTAR PUSTAKA}

Adisubrata, W. S. (1999). Otonomi daerah di era reformasi. Upp Amp Ykpn.

Arwakom, K, Syaikhul Falah, Anthonius Citra. (2015). Analisis Hubungan Antara

Pertumuhan Ekonomi Daerah dan Belanja Modal Terhadap Pendapatan Asli

Daerah Kabupaten Supiori. KEUDA: JURNAL KAJIAN EKONOMI DAN KEUANGAN DAERAH, Vol 1.

Basri, H. (2006). Potret Pengelolaan Keuangan Daerah dan Pelayanan Publik.

Didi Yigibalom, Ida Ayu Purba Riani. (2015). Analisis Kinerja Pendapatan dan Belanja

Daerah Kabupaten Jayawijaya Tahun 2010-2014. KEUDA: JURNAL KAJIAN EKONOMI DAN KEUANGAN DAERAH, Vol 1.

Efendi, D., \& Wuryanti, S. (2011). Analisis Perkembangan Kemampuan Keuangan Daerah Dalam Mendukung Pelaksanaan OTODA di Kabupaten nganjuk. In PROSIDING SEMINAR NASIONAL \& INTERNASIONAL (Vol.1).

Halim, A. (2001). Bunga rampai manajemen keuangan daerah. Edisi Pertama. Yogyakarta: UPP AMP YKPN.

Halim, A., \& Abdullah, S. (2010). Hubungan dan Masalah Keagenan di Pemerintah Daerah. Jurnal Akuntansi Pemerintah, 2(1), 53-64.

Hengki Derek Wandosa, Arius Kambu, Agustinus Numberi. (2015). Analisis Faktor-

Faktor Yang Mempengaruhi Pendapatan Asli Daerah Kabupaten Mimika. KEUDA : JURNAL KAJIAN EKONOMI DAN KEUANGAN DAERAH, Vol 1.

Hidayati, I. F. (2014). Analisis Pengaruh Kesadaran Wajib Pajak, Pengetahuan dan Pemahaman Tentang Peraturan Perpajakan, Efektifitas Sistem Perpajakan, Pelayanan Fiskus, dan Sanksi Pajak Terhadap Kepatuhan Wajib Pajak Orang Pribadi (Studi Kasus pada KPP Pratama Surakarta). Universitas Muhammadiyah Surakarta.

Hoessein, B. (2000). Otonomi Daerah Dalam Negara Kesatuan Sebagai Tanggap

Terhadap Aspirasi Kemajemukan Masyarakat dan Tatangan Globalisasi. Jurnal Usahawan, (04).

Jikwa, E., Agustinus Salle, Paulus K. Allo Layuk. (2016). Pengaruh Pendapatan Transfer dan Silpa Terhadap Belanja Modal di Kabupaten Mamberamo Tengah. KEUDA : JURNAL KAJIAN EKONOMI DAN KEUANGAN DAERAH, Vol 1.

Jonathan, S. (2006). Metode penelitian kuantitatif dan kualitatif. Graha IImu. Kifliansyah. (2001). Analisa Realisasi Anggaran Pendapatan dan Belanja Daerah.

La Ode Abdul Wahab, Siti Rofingatun, Balthazar K. (2016). Analisis Kemampuan Keuangan Daerah Pemerintah Kabupaten Jayapura. KEUDA : JURNAL KAJIAN 
EKONOMI DAN KEUANGAN DAERAH, Vol 1.

Manasep Orocomna, B. Elita, Paulus K. Allo Layuk. (2016). Faktor-Faktor Yang Mempengaruhi Kemandirian Daerah Kabupaten Teluk Bintuni Tahun 2010-2015. KEUDA : JURNAL KAJIAN EKONOMI DAN KEUANGAN DAERAH, Vol 1.

Mardiasmo (2009:3). (2015). Efektivitas dan Kontribusi Penerimaan Pajak Hotel dan Restoran terhadap PAD Kota Manado. Perpajakan, 1(3), 2007-2011. https://doi.org/10.1017/CBO9781107415324.004

Mulyana, B. (2006). Pengaruh penyajian neraca daerah dan aksesibilitas laporan keuangan terhadap transparansi dan akuntabilitas pengelolaan keuangan daerah. Universitas Gadjah Mada.

Sidik, M. (2002). Optimalisasi pajak daerah dan retribusi daerah dalam rangka meningkatkan kemampuan keuangan daerah. Makalah Disampaikan Acara Orasi IImiah. Bandung, 10.

Suparmoko, M. (2002). Ekonomi Publik untuk Keuangan dan Pembangunan Daerah. Andi.

Triastuti, M. R. H., \& Darwin, M. (2005). Analisis Kemandirian Keuangan Daerah Kota Yogyakarta (Studi Tentang Desentralisasi dan Otonomi Fiskal Daerah)= Analysis of Local Financial Independency in Yogyakarta Municipality (Study About Local Fiscal Autonomy and D. Sosiosains, 18(2005).

Yani, A. (2002). Hubungan keuangan antara pemerintah pusat dan daerah di Indonesia. Divisi Buku Perguruan Tinggi, RajaGrafindo Persada. 